cowania Profesora: Księżniczka i chudopachołek. Zofia z Radziwitłów Dorohostajska - Stanisław Tymiński (Opole 1995; została przetłumaczona na język litewski), która poświęcona została m.in. ukazaniu staropolskiego romansu, wskazaniu arkanów prawa, moralności, postaw, zachowań ludzi możnych.

W refleksji uogólniającej, wskazując na wartości poznawcze prezentowanej książki można skonstatować, że:

1) jest ona swoistym wprowadzeniem do monograficznego ukazania kresów w dziejach państwa polskiego;

2) dostarcza się w niej wiedzy dotyczącej polskich badaczy spraw kresowych oraz ich osiągnięć poznawczych istotnych z punktu widzenia prezentacji stanu badań;

3) wskazuje się na kwestie metodologiczne, zwłaszcza dotyczące relacji: rzeczy-

Wojciech Jaruzelski, Starsi o 30 lat, Wydawnictwo Adam Marszałek, Toruń 2011, ss. 205.

Niewielu polityków możemy zaliczyć do grona nauczycieli narodu, ich wypowiedzi jednak są szczególnej wagi i zajmują trwałe miejsce w edukacji politycznej społeczeństwa. Bez watpienia do tego grona zaliczony zostanie przez przyszłe pokolenia pierwszy prezydent Rzeczypospolitej odrodzonej w 1989 r. w wyniku symbolizowanych data 4 czerwca przemian ustrojowych. Zostanie - jako że dzisiaj jego publicystyka ma ograniczony zasięg, świadomie bowiem jest on ograniczany przed opinią publiczną przez przemożnych przeciwników. Sędziwy mąż stanu (ur. 1923) przez dwa dziesięciolecia po opuszczeniu czynnej sceny państwowej musiał koncentrować siły na zbijaniu argumentów swych przeciwników, natomiast w sygnalizowanej w nagłówku najnowszej pozycji, którą ogłosił w 30 rocznicę stanu wojennego przedstawił syntetyczny obraz najnowszych wistość kulturowa a legenda o kresach wschodnich;

4) określa się wagę i nośność badania kwestii kresowych, zwłaszcza w sytuacji uwarunkowań ideologiczno-politycznych czy tzw. poprawności politycznej;

5) dostarcza się bogatej warstwy faktograficznej oraz eksplanacyjnej o kresach, nierzadko podkreślając różnice w ich postrzeganiu przez uczonych białoruskich, litewskich, ukraińskich i polskich.

Książka wzbogaca wiedzę kresoznawczą i zasługuje na uwagę szerokiego kręgu czytelników.

\section{Andrzej CHODUBSKI}

Gdańsk

dziejów, w którym odegrał trudną do przecenienia rolę, $\mathrm{z}$ charakterystyczną dla siebie erudycją sięgnął do losów narodu w czasach porozbiorowych, prezentując wykład w sposób logiczny, piękną polszczyzną, jakże rzadką w dzisiejszym piśmiennictwie zachwaszczonym neologizmami i makaronizmami. W Słowie wstepnym nie zapomniał o drze Adamie Marszałku, toruńskim wydawcy wielu swych prac, który z odwagą je ogłaszał drukiem w latach, kiedy ludzie małej wiary usiłowali propagować wypaczony negatywnie wizerunek Generała.

W 2008 r. ukazała się poprzednia książka Wojciecha Jaruzelskiego, pod znamiennym tytułem: Być może to Ostatnie słowo (Wyjaśnienia złożone przed Sadem). Na uwagę zasługuje owo zastrzeżenie: być może... Najwybitniejszy w moim przekonaniu mąż stanu w Polsce drugiej połowy XX wieku, który 
odegrał rolę analogiczną do Józefa Piłsudskiego w pierwszej połowie minionego stulecia, przywódca państwowy czasu wielkich przemian, nie zaprzestał walki piórem w obronie swych racji nawet na łożu szpitalnym, kiedy nadchodziła trzydziesta rocznica 13 grudnia.

Najnowsza książka Generała w moim przekonaniu stanowi wyjątkowe przesłanie do współczesnych pokoleń i podręcznik wychowania obywatelskiego. Zasadnicze w niej miejsce zajmuje gruntownie uzasadniona odpowiedź na pytanie: czy musiało dojść do wprowadzenia stanu wojennego. Kwestii tej dotyczą obszerne aneksy, zwłaszcza tekst wystapienia podczas konferencji zorganizowanej dnia 9 listopada 2010 r. przez Akademię Humanistyczną im. Aleksandra Gieysztora w Pułtusku oraz wywiad dla tygodnika „Przegląd" w dziewiętnastą rocznicę Spotkania Trzech (Jaruzelski - Glemp - Wałęsa) $\mathrm{z}$ dnia 6 listopada $2000 \mathrm{r}$.

Zasadniczy tekst stanowi wzorowy wykład edukacyjny dotyczący najnowszych dziejów Polski oparty o gruntowną znajomość współczesności z uwzględnieniem narodowych tradycji sięgających czasów porozbiorowych. Mówią za siebie nagłówki kolejnych, przeważnie kilkustronicowych rozdziałów, których jest niemal pięćdziesiąt (s. 9-160), pod wymownymi nagłówkami, jak: Jestem Strona, Znamienne zaniechania, Próba generalna, Jak z historia?, Ku porozumieniu, Wojny nie chciat nikt, Gospodarcze ultimatum, W ramionach $R W P G$, Porozumienie $i$ walka, Trzeba byto rozmawiać, Decyzję podjęliśmy w Polsce, Oczy otwarte, Jaka pamięć?, Okupacja, czy wyzwolenie? Państwo - Kościót, Polska impulsem i wzorem, Gorzka satysfakcja.

Ten traktat historyczno-pedagogiczny zasługuje na wnikliwą analizę i trwałe miejsce w naszym piśmiennictwie. Na pierwszą wypadnie nieco poczekać, co do drugiej dziś trudno mieć większe złudzenia. W środkach masowego przekazu dominują ekscytujące odbiorcę (natrętnie mu narzucane!) jednowy- miarowe scenki, choć nie mógł nie dostrzec znamiennego spotkania w szpitalnej scenerii trzech kolejnych prezydentów wywodzących się z różnych stron politycznej barykady i reprezentujących różne generacje: Lecha Wałęsy u Wojciecha Jaruzelskiego oraz tegoż u Aleksandra Kwaśniewskiego, gdy na ekranie włączonego telewizora pojawił się Wałęsa.

Autor w Stowie wstepnym napisał: Każdy ma prawo do własnej oceny. Jednakże nienaruszalna zasada być powinno - bez przyczyn nie ma skutków! W tej materii jest wiele „, biatych plam”- znamiennych luk, sptyceń, uników. Ta ksiażka konsekwentnie je obnaża. Jednocześnie nie uchylam się od krytyki minionego systemu, jego schorzeń i popetnionych wówczas blędów. Niestety, ,huragan” psychologiczno-propagandowy - w każda rocznice wprowadzenia stanu wojennego - ma zastapić rzetelnq, obiektywnq analizę ówczesnej sytuacji. 30 rocznica niewatpliwie to potwierdzi.

I potwierdziła. Tyle że niespodziewanie w zgoła groteskowej postaci. Oto bowiem ci, którzy swego czasu znajdowali się w owej przysłowiowej solidarnościowej czwartej brygadzie, a obecnie stanowią, ,jedynie słuszną" patriotyczną siłę, tym razem 13 grudnia Anno Domini 2011 manifestacyjnie zwrócili się nie tylko przeciw twórcom, ,zbrodniczego stanu wojennego", ale i zaatakowali obecne kierownictwo państwowe.

W wystapieniu na wspomnianej konferencji w Pułtusku Wojciech Jaruzelski nie pominął manipulacji propagandowych i wspomniał o służących ofiarnie tej sprawie swych autorytetem i nie zawsze udokumentowanymi tytułami profesorskimi ,dyżurnych telewizyjnych historykach”. Na innych miejscach nie bez goryczy przypominał swe listy do młodszych o kilkadziesiąt lat osób publicznych, zwłaszcza funkcjonariuszy Instytutu Pamięci Narodowej (!), które nie były łaskawe odpowiedzieć i wystapienia byłego prezydenta zbywały milczeniem. Nie zapominał o wąskim oddziaływaniu swych publikacji oraz materiałów źródłowych, co nie 
było kwestią przypadku, bowiem jak piszą wydawcy Ostatniego słowa, stanowią one materiat bardzo niewygodny, a nawet wstydliwy dla tych osób i kręgów politycznych, którzy stan wojenny $i$ w ogóle cała historie Polski Ludowej - bez uwzględnienia uwarunkowań i zróżnicowań - totalnie potępiaja $i$ oskarżaja. Traktują bowiem nie tylko przeszłość, którą łatwo manipulować, ale pozostającą w pamięci żyjących pokoleń w wymiarach baśniowych i barwach czarno białych. Na wnikliwą lekturę zasługuje cały tekst, w tym aneksy, a w nich wspomniany wywiad z 6 listopada 2000 r. - zawarte w nim oceny oddają sprawiedliwość dawnym antagonistom i stanowią dobrą szkołę kultury po- litycznej. Podkreślają doniosłą rolę Kościoła katolickiego, a zwłaszcza ówczesnego prymasa J. Glempa i nuncjusza J. Kowalczyka, który nie krył swego zrozumienia dla politycznych uzasadnień stanu wojennego przy uwzględnieniu realiów międzynarodowych tamtego czasu, przypomniał też dwie drogi do samodzielności z jesieni 1946 r., polskiej i węgierskiej oraz skutki przyjętych wówczas rozwiązań.

Spoglądając na tytuł książki chciałoby się nieco go poszerzyć i zapytać: $O 30$ lat starsi, ale czy madrzejsi?
Marceli KOSMAN

Poznań 